\title{
EFEK MULTIPLIER ZAKAT TERHADAP PENDAPATAN DI PROVINSI DKI JAKARTA
}

\author{
M Nur Rianto Al Arif*
}

\begin{abstract}
Multiplier effects of the Zakat Revenue in DKI Jakarta. The aim of this research is to analyse the multiplier effect of zakâh revenue in DKI Jakarta. A study case at Badan Amil Zakat, Infak, and Sadaqah (BAZIS) DKI Jakarta. Least square method is used to analyze the data. The coefficients will be used to calculate the multiplier effect of zakâh-revenue and it twill be compared with the economy without zakah revenue. The results showed 2,522 multiplier effects of zakâh-revenue and 3.561 multiplier effect of economic income without zakâh-revenue. This suggests that the management of zakat in BAZIS Jakarta still can have a significant influence on the economy.
\end{abstract}

Keywords: multiplier effect, two stage least square, zakâh

Abstrak: Efek Multiplier Zakat terhadap Pendapatan di Provinsi DKI Jakarta. Studi ini dimaksudkan untuk menganalisis pengaruh multiplier zakat terhadap pendapatan di DKI Jakarta, studi kasus pada Badan Amil Zakat, Infak, dan Shadaqah (BAZIS) DKI Jakarta. Adapun analisis datanya menggunakan metode least square. Kemudian koefisiennya digunakan untuk menghitung efek multiplier dari zakat pendapatan. Lalu, data tersebut dibandingkan dengan perekonomian tanpa zakat-pendapatan. Hasil penelitian ini menunjukkan 2,522 efek multiplier zakat-pendapatan dan 3,561 efek multiplier dari pendapatan ekonomi tanpa zakat-pendapatan. Hal ini menunjukkan bahwa pengelolaan zakat di BAZIS DKI Jakarta masih belum dapat memberikan pengaruh yang signifikan terhadap ekonomi.

Keywords: efek multiplier, dua tahap least square dan zakat

Naskah diterima: 1 Oktober 2011, direvisi: 1 Desember 2011, disetujui: 8 Desember 2011.

* Ikatan Ahli Ekonomi Islam Indonesia (IAEI). Jl. Gedung RM. Noto Hamiprodjo Lt. 1, Jln. Dr. Wahidin 1, Senen Raya, Jakarta Pusat. E-mail: agif08@gmail.com. 


\section{Pendahuluan}

Kemiskinan merupakan permasalahan yang selalu timbul di setiap negara, baik itu kemiskinan absolut maupun kemiskinan relatif. Walaupun sudah banyak program-program yang ditujukan dalam upaya pengentasan kemiskinan, namun masalah ini tidak kunjung selesai. Sulitnya penyelesaian masalah ini disebabkan permasalahan yang melibatkan penduduk miskin ternyata sangat kompleks. Pendekatan dalam penyelesaiannya tidak hanya dilakukan dari segi ekonomi saja, namun segi sosialnya harus dipertimbangkan. Faktor utama penyebab kemiskinan sebagian besar karena faktor alamiah. Selain itu tidak terjadinya pemerataan hasil pembangunan juga merupakan faktor penyebab yang tidak dapat diabaikan.

Krisis ekonomi yang melanda Indonesia sejak pertengahan 1997, diyakini berakibat buruk bagi kesejahteraan masyarakat, sehingga tingkat kemiskinan juga akan meningkat. Sampai dengan 1996, jumlah penduduk miskin di Indonesia mengalami penurunan. Penurunan ini tidak hanya terlihat dari jumlah absolutnya, tetapi lebih dari itu persentase penduduk miskin juga selalu mengalami penurunan. Krisis ekonomi yang melanda Indonesia pada Juli 1997 berakibat pada jumlah penduduk miskin yang tadinya mengalami penurunan, kembali mengalami peningkatan. Dalam upaya untuk mengatasi kemiskinan, pemerintah telah mengeluarkan berbagai kebijakan agar permasalahan kemiskinan ini dapat terselesaikan, antara lain dengan kebijakan Inpres Desa Tertinggal (IDT) dan Jaring Pengaman Sosial (JPS) yang dikeluarkan pada saat krisis. Namun semuanya masih belum dapat menyelesaikan permasalahan ini.

Timbul suatu pertanyaan tentang bagaimanakah penanganan masalah kemiskinan di Ibukota negara kita DKI Jakarta? Apakah Pemerintah Provinsi setempat telah memiliki kebijakan komprehensif dan terarah dalam menangani masalah ini? Telah banyak program pengentasan kemiskinan di DKI Jakarta, baik dari pemerintah pusat maupun dari Pemerintah Provinsi DKI Jakarta sendiri. Semua program yang telah ditempuh pada dasarnya telah memberikan hasil yang menggembirakan, terlihat pada semakin menurunnya penduduk miskin di DKI Jakarta, meskipun pada saat krisis ekonomi jumlah ini meningkat kembali secara drastis. Usaha yang telah dilakukan ini dampaknya masih belum dirasakan secara optimal oleh masyarakat. Di mana dalam evaluasi pelaksanaan program pengentasan kemiskinan tahun 2000 program yang tepat sasaran hanya $30,52 \%$ saja, sedangkan $41,81 \%$ tidak, serta $27,67 \%$ tidak diketahui (BPS: 2001).

Hal ini menyebabkan perlunya dukungan dari sub-sistem pengentasan kemiskinan yang lain di mana BAZIS DKI Jakarta selaku perangkat Pemerintah 
Provinsi DKI Jakarta yang bertugas mengelola zakat di DKI Jakarta, mengambil peranan pula dalam pelaksanaan pengentasan kemiskinan di DKI Jakarta terutama dalam mengangkat perekonomian umat. Seberapa jauhkan? peranan BAZIS DKI Jakarta dalam memotong lingkaran kemiskinan? Dari ketiga faktor tersebut yang sudah tersentuh secara langsung oleh BAZIS DKI Jakarta adalah kualitas sumber daya manusia dan akses permodalan, sedangkan tentang akses kepemilikan sumber daya merupakan bagian dari kebijakan pembangunan yang dilaksanakan pemerintah.

Seberapa jauh peranan yang telah diambil BAZIS DKI Jakarta dalam mengentaskan kemiskinan terutama dalam menanggulangi dampak krisis ekonomi? Hal ini dikarenakan persentase kenaikan penerimaan zakat tidak diimbangi secara proporsional oleh penurunan tingkat kemiskinan. Melihat pada peranan yang dilakukan BAZIS DKI Jakarta, bahwasanya telah terjadi perubahan dalam pendayagunaan zakat bagi fakir miskin dari yang sebelumnya hanya 55\% dari total dana yang ada menjadi $75 \%$. Masih belum optimalnya program pengentasan kemiskinan yang dilakukan mungkin dikarenakan efek multiplier daripada zakat terhadap pendapatan yang masih kecil. Sehingga peningkatan penerimaan zakat kurang mempengaruhi jumlah penduduk miskin yang digambarkan dengan tingkat pendapatan per kapita.

Alasan pemilihan DKI Jakarta sebagai objek penelitian adalah karena berdasarkan data BPS, penduduk Muslim DKI Jakarta mempunyai persentase di atas 70\%, sehingga seharusnya pengelolaan zakat di Provinsi DKI Jakarta dapat memberikan pengaruh positif dalam pengentasan kemiskinan. Selain itu, bila dibandingkan dengan Badan Amil Zakat (BAZ) lainnya yang dikelola oleh Pemerintah, BAZIS DKI Jakarta adalah badan amil zakat yang paling lama berdiri bila dibandingkan dengan Badan Amil Zakat di provinsi lain. Sehingga dalam hal pengumpulan dan pengelolaan dana zakat, infak, dan sadaqah, BAZIS DKI Jakarta jauh lebih baik daripada BAZ Provinsi lainnya. Kemudian BAZIS DKI Jakarta merupakan salah satu Badan dalam pemerintahan Provinsi DKI Jakarta yang secara khusus menangani pengelolaan dana zakat.

Allah Swt. berfirman:

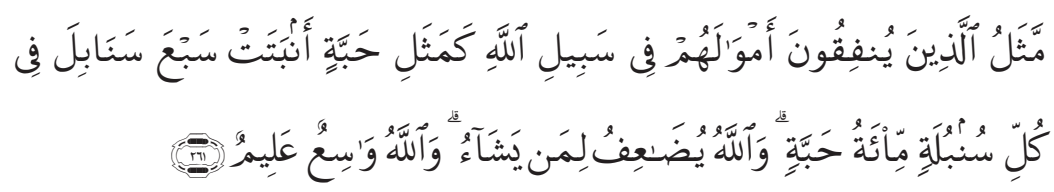


Perumpamaan (nafkah yang dikeluarkan oleh) orang-orang yang menafkahkan hartanya di jalan Allah adalah serupa dengan sebutir benih yang menumbuhkan tujuh bulir, pada tiap-tiap bulir: seratus biji. Allah melipatgandakan (ganjaran) bagi siapa yang Dia kehendaki. Dan Allah Mahaluas (karunia-Nya) lagi Maha Mengetahui. (Q.s. al-Baqarah [2]: 261)

Berdasarkan ayat di atas, digambarkan bahwa zakat sebagai salah satu instrumen dalam Islam sebagai alat pengentasan kemiskinan ternyata mempunyai efek multiplier terhadap pendapatan, di mana hal ini dinyatakan dengan sebutir benih yang menumbuhkan tujuh bulir dan tiap-tiap bulir seratus biji.

\section{Permasalahan}

Berdasarkan uraian di atas, berdasarkan teori yang ada seharusnya dengan penerimaan zakat yang selalu meningkat dari tahun ke tahun akan mampu menurunkan tingkat kemiskinan. Namun kenyataannya yang terjadi peningkatan penerimaan dana zakat ternyata masih belum mampu menurunkan tingkat kemiskinan. Hal ini menunjukkan bahwa pengelolaan zakat yang dikelola oleh BAZIS DKI Jakarta belum mampu memberikan pengaruh terhadap pendapatan. Sehingga rumusan masalah dalam penelitian ini adalah mengapa pengelolaan zakat oleh BAZIS DKI Jakarta belum memberikan pengaruh yang signifikan kepada tingkat pendapatan di Provinsi DKI Jakarta? Berikut ini rumusan pertanyaan penelitiannya: (1) Seberapa besar efek multiplier dana zakat yang dikelola oleh BAZIS DKI Jakarta dalam mengentaskan kemiskinan di Jakarta dan mampu meningkatkan kesejahteraan mereka yang dilihat dari pendapatan per kapita? (2) Bila dibandingkan dengan perekonomian tanpa memasukkan unsur zakat di dalamnya, manakah yang lebih baik, apakah perekonomian dengan zakat atau tanpa zakat?

Hal ini kemungkinan disebabkan oleh beberapa hal: (1) Zakat belum memiliki efek multiplier yang cukup besar terhadap pendapatan; (2) Masih jauhnya realisasi penerimaan dana zakat dibandingkan dengan potensinya; (3) Penggunaan dana zakat yang masih kurang tepat sasaran. Batasan penelitian yang dibahas dalam penelitian ini adalah hanya untuk melihat besaran efek multiplier zakat terhadap pendapatan, sebagai salah satu cara untuk melihat efektifitas pengelolaan zakat oleh BAZIS DKI Jakarta, serta implikasinya terhadap penurunan tingkat kemiskinan. 
Gambar 1

Kerangka PemikiranTeoritis

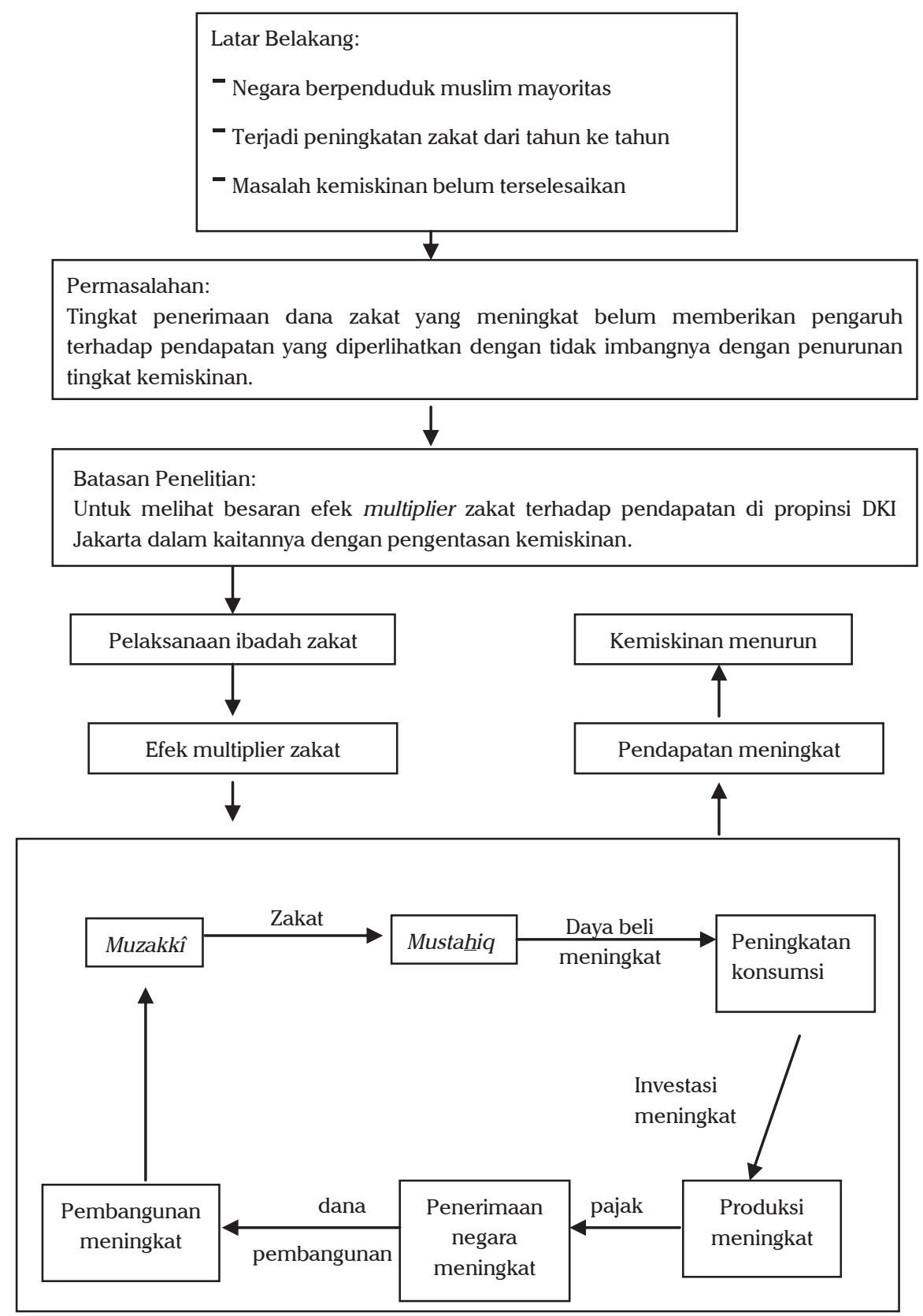




\section{Metode Analisis}

Metode analisis adalah suatu cara yang didapatkan dalam suatu penelitian untuk menganalisis data yang diperoleh agar mendapatkan suatu hasil penelitian yang sempurna dari segi teoritis empiris serta dapat digunakan sebagai bahan masukan dalam kebijakan ekonomi pemerintah.

Metode analisis yang dipergunakan dalam penelitian ini adalah metode penelitian empiris menggunakan regresi dengan two stage least square. Kemudian hasil yang didapat dimasukkan ke dalam persamaan multiplier zakat yang telah diturunkan dari model persamaan yang ada.

Dalam perekonomian tiga sektor keseimbangan pendapatan nasional dicapai apabila penawaran agregat adalah sama dengan permintaan agregat. Perekonomian yang digunakan dalam persamaan ini adalah perekonomian tiga sektor karena diasumsikan setiap ekspor dan impor yang terkait dengan perdagangan ditangani langsung oleh pemerintah pusat. Sehingga variabel ekspor dan impor ditiadakan dalam model persamaan ini.

Penawaran agregat=permintaan agregat. Atau $\mathrm{Y}=\mathrm{C}+\mathrm{I}+\mathrm{G}$. $\mathrm{Y}$ adalah pendapatan regional bruto Provinsi DKI Jakarta; $\mathrm{C}$ adalah konsumsi masyarakat termasuk konsumsi rumah tangga dan swasta; I adalah tingkat investasi di Provinsi DKI Jakarta; G adalah pengeluaran Pemerintah Provinsi DKI Jakarta.

Sedangkan ditinjau dari aliran pendapatan, dalam perekonomian tiga sektor berlaku kesamaan berikut: $\mathrm{Y}=\mathrm{C}+\mathrm{S}+\mathrm{T}$. Di mana: $\mathrm{Y}$ adalah pendapatan regional bruto Provinsi DKI Jakarta. C adalah konsumsi masyarakat termasuk konsumsi rumah tangga dan swasta. $\mathrm{S}$ adalah tingkat tabungan masyarakat. $\mathrm{T}$ adalah tingkat penerimaan pajak yang diterima oleh pemerintah. Dengan demikian pada keseimbangan pendapatan nasional berlaku kesamaan berikut: $\mathrm{C}+\mathrm{I}+\mathrm{G}=\mathrm{C}+\mathrm{S}+\mathrm{T}$. Apabila $\mathrm{C}$ dikurangi dari setiap ruas, maka: $\mathrm{I}+\mathrm{G}=\mathrm{S}+\mathrm{T}$.

Dalam perekonomian tiga sektor I dan G adalah bocoran dari sirkulasi aliran pendapatan, sedangkan $\mathrm{S}+\mathrm{T}$ adalah suntikan. Dengan demikian dalam keseimbangan ekonomi tiga sektor juga berlaku keadaan: bocoran=suntikan Sebagai kesimpulan dapatlah dirumuskan bahwa dalam perekonomian tiga sektor yang mencapai keseimbangan akan berlaku keadaan sebagai berikut: $\mathrm{Y}=\mathrm{C}+\mathrm{I}+\mathrm{G}$ dan $\mathrm{I}+\mathrm{G}=\mathrm{S}+\mathrm{T}$. Model yang digunakan dalam penelitian ini adalah: $\mathrm{Y}=\mathrm{C}+\mathrm{I}+\mathrm{G}$. Di mana: $\mathrm{I}=\mathrm{Io} ; \mathrm{G}=\mathrm{Go} ; \mathrm{C}=\mathrm{a}+\mathrm{b}(\beta \mathrm{Y}-\alpha \mathrm{Y})+\delta[(1-\beta) \mathrm{Y}+\alpha \mathrm{Y}]+\mu_{\mathrm{t}} . \mathrm{C}$ adalah fungsi konsumsi yang merupakan fungsi dari pendapatan muzakkî (orang yang membayar zakat) dan mustahiq (orang yang menerima zakat). Pendapatan muzakkî ditunjukkan pada persamaan ( $\beta Y-\alpha Y)$, di mana pendapatan muzakkî bersih adalah pendapatan muzakkî ( $\beta Y$ ) dikurangi dengan zakat ( $\alpha Y$ ). Pendapatan mustahiq ditunjukkan pada persamaan $[(1-\beta) \mathrm{Y}+\alpha \mathrm{Y}]$, di mana penda- 


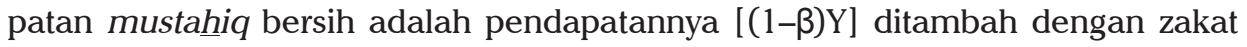
( $\alpha$ Y) yang diterima.

Zakat dalam persamaan ini diperlakukan sebagai pengeluaran konsumsi. Sehingga: $Y=a+b \quad(\beta Y-\alpha Y)+\delta[(1-\beta) Y+\alpha Y]+I_{0}+G o+\mu_{t} ; \quad Y=a+b \beta Y-b \alpha Y+\delta \quad(1-\beta) Y-$ $\delta \alpha Y+I_{0}+G o+\mu_{t} ; \quad Y-Y \quad(b(\beta+\alpha)-\delta \quad[(1-\beta)+\alpha])=a+\operatorname{Io}+G o+\mu_{t}$. Bila diasumsikan: $\mathrm{A}=\mathrm{a}+\mathrm{Io}+\mathrm{Go}+\mu_{\mathrm{t}}$, Maka $Y(1-[\mathrm{b}(\beta+\alpha)-\delta[(1-\beta)+\alpha]=A$.

$$
Y=\frac{1}{1-[b(\beta+\alpha)]-[\delta(1-\beta)+\alpha]} A
$$

Maka multiplier zakat-pendapatan adalah:

$$
K=\frac{1}{1-[b(\beta+\alpha)]-[\delta(1-\beta)+\alpha]}
$$

diasumsikan bahwa: $Z_{1}=b(\beta+\alpha) ; Z_{2}=\delta[(1-\beta)+\alpha]$

Maka: $K=\frac{1}{1-Z_{1}-Z_{2}}$

Dimana: $\mathrm{Z}_{1}$ adalah kecenderungan mengkonsumsi muzakkî; $\mathrm{Z}_{2}$ adalah kecenderungan mengkonsumsi mustahiq.

Pada model persamaan di atas zakat diperlakukan tidak sama seperti pajak, melainkan diperlakukan sebagai salah satu pengeluaran konsumsi masyarakat untuk akhirat. Meskipun zakat yang dikeluarkan tersebut dapat berguna pula bagi sosial kemasyarakatan. Model persamaan konsumsi di atas menggunakan model absolute income hypothesis yang dikemukakan oleh Metwally, di mana menurut hipotesa ini konsumsi seseorang tergantung sepenuhnya kepada pendapatan saat ini. Hal ini sejalan dengan teori yang ada, di mana mustahiq dalam konsumsinya sangat bergantung pada besaran pendapatan yang diterimanya saat ini.

Persamaan konsumsi yang ada merupakan komponen dari pendapatan bersih muzakkî yaitu pendapatan yang telah dikurangi kewajiban zakat. Hal ini terlihat dalam persamaan ( $\beta Y-\alpha Y$ ). $\beta Y$ merupakan pendapatan yang diterima oleh muzakkî, sementara aY merupakan kewajiban zakat yang harus dikeluarkan. Sedangkan komponen kedua dalam persamaan konsumsi adalah pendapatan bersih mustahiq yaitu pendapatan yang telah ditambah oleh zakat yang diterima dari orang yang berkecukupan. Ini terlihat dalam persamaan konsumsi kedua $[(1-\beta) \mathrm{Y}+\alpha \mathrm{Y}]$, di mana $(1-\beta) \mathrm{Y}$ merupakan pendapatan yang dimiliki oleh mustahiq. Sedangkan $\alpha \mathrm{Y}$ merupakan zakat yang didapat oleh mustahiq dari individu yang berkecukupan.

Persamaan identitas menggunakan persamaan dalam perekonomian tiga sektor di mana Pendapatan Domestik Bruto (Y) ditentukan oleh Konsumsi (C), 
Investasi (I), dan Pengeluaran Pemerintah (G). Hal ini dilakukan karena objek penelitian adalah Provinsi DKI Jakarta.

Model ekonomi makro, dianalisis dengan ekonometrika berdasarkan pendekatan persamaan simultan (simultaneous equation). Persamaan simultan adalah suatu proses estimasi lebih dari satu persamaan dalam satu waktu. Alasan penggunaan 2SLS adalah karena persamaan yang digunakan dalam penelitian ini adalah suatu model persamaan simultan yang tidak dapat dianalisis dengan metode regresi OLS biasa.

Hasil perhitungan yang didapat pada persamaan di atas, kemudian diperbandingkan dengan hasil perhitungan yang didapat pada persamaan ekonomi konvensional. Adapun persamaan ekonomi konvensional adalah sebagai berikut: $\mathrm{Y}=\mathrm{C}+\mathrm{I}+\mathrm{G}$, di mana: $\mathrm{I}=\mathrm{Io}, \mathrm{G}=\mathrm{Go}, \mathrm{C}=\mathrm{a}+\mathrm{bY}$. Sehingga menjadi:

$\mathrm{Y}=\mathrm{a}+\mathrm{bY}+\mathrm{Io}+\mathrm{Go}+\mu ; \mathrm{Y}-\mathrm{bY}=\mathrm{a}+\mathrm{Io}+\mathrm{Go}+\mu$.

Selanjutnya menjadi: $Y=\frac{1}{(1-b)} a+I o+G o$

Sehingga multiplier pendapatan adalah: $Y=\frac{1}{(1-b)}$

Proses analisis menggunakan pendekatan two stage least square (2SLS), ada dua langkah dalam proses analisis yang dilakukan, yaitu: (1) Untuk menghilangkan unsur korelasi, regresi persamaan yang pertama pada semua variabel eksogen di dalam sistem persamaan simultan. (2) Pada langkah kedua menggantikan nilai yang ada pada persamaan dengan nilai yang telah kita dapat dari persamaan reduced form dan kemudian melakukan regresi dengan metode OLS. (3) Sifat-sifat penaksir pada 2SLS adalah: Pertama, dapat diterapkan pada persamaan individu dalam sistem tanpa melakukan perhitungan terhadap persamaan lainnya. Kedua, walaupun secara khusus digunakan untuk persamaan yang over-identified akan tetapi dapat digunakan untuk persamaan yang exactly identified. Ketiga, jika pada langkah pertama $\mathrm{R}^{2}>0.8$ maka OLS dan 2SLS akan menghasilkan taksiran yang cenderung sama, sebaliknya jika pada langkah pertama $\mathrm{R}^{2}$ rendah maka 2 SLS kurang berarti. Keempat, dengan metode ILS, kesalahan baku koefisien tidak bisa dilaporkan sedangkan metode 2SLS dilaporkan. Kelima, menurut Henry Theil, bila lag endogenous variable tidak ada maka koefisien hasil taksiran 2SLS adalah konsisten bila variabel eksogen konstan pada sampel berulang dan jika disturbance term error IID.

Namun sebelum dilakukan pengujian menggunakan two stage least square perlu dilakukan identifikasi model terlebih dahulu. Masalah identifikasi dimaksudkan apakah penaksiran numeris parameter persamaan struktural dapat 
diperoleh dari taksiran koefisien reduced-form. Jika taksiran koefisien persamaan struktural dapat dihasilkan dari taksiran koefisien reduced-form maka persamaan tertentu dikatakan teridentifikasi atau identified, jika tidak maka persamaan tertentu dikatakan unidentified atau underidentified. Persamaan teridentifikasi terdiri dari dua tipe, yaitu exactly identified dan overidentified. Satu persamaan dikatakan exactly identified bila nilai numeris parameter struktural adalah unik yang diperoleh dari reduced-form equation, dan satu persamaan dikatakan overidentified bila nilai numeris parameter struktural lebih dari satu yang diperoleh dari reduced-form equation. Penentuan identifikasi persamaan simultan melalui reduced-form equation pada umumnya tidak digunakan. Metode umum identifikasi model persamaan simultan adalah order and rank conditions of identification.

Aturan yang dilakukan adalah: $\mathrm{K}-\mathrm{k}>\mathrm{m}-$. Di mana: $\mathrm{M}=\mathrm{jumlah}$ variabel endogen dalam model; $m=$ jumlah variabel endogen pada persamaan tertentu; $\mathrm{K}=\mathrm{jumlah}$ variabel predetermin dalam model termasuk titik potong; $\mathrm{k}=\mathrm{jumlah}$ variabel predetermin pada persamaan tertentu.

Dalam model di atas jumlah variabel endogen ada dua yaitu $\mathrm{Y}$ dan $\mathrm{C}$. Sementara variabel eksogen dalam model ini ada empat yaitu I, G, Yzm, dan Yzs. Persamaan identitas, dalam persamaan ini terdapat dua variabel eksogen dan dua variabel endogen, sehingga 4- 2>2-1. Jadi persamaan identitas dapat dikatakan terlalu teridentifikasi (overidentified).

Sedangkan dalam persamaan konsumsi terdapat satu variabel endogen dan dua variabel eksogen, sehingga 4-2>1-1, jadi persamaan konsumsi dapat dikatakan terlalu teridentifikasi (overidentified). Karena model persamaan simultan dalam penelitian ini adalah terlalu teridentifikasi (overidentified). Maka model penelitian di atas diolah dengan menggunakan metode two stage least squares (2SLS). Setelah dilakukan pengolahan regresi menggunakan two stage least square, perlu dilihat apakah model tersebut baik ataukah jelek, atau dalam bahasa statistik perlu dilihat goodness of fit dari model tersebut. Untuk melihat goodness of fit dari model dengan melihat pada hasil t statisktik, F statistik, koefisien determinasi $\left(\mathrm{R}^{2}\right)$, serta pengujian asumsi klasik yang meliputi heterokedastisitas, autokorelasi, dan multikolinearitas.

Pengujian $\mathrm{t}$ statistik adalah suatu prosedur dengan sampel yang digunakan untuk verifikasi kebenaran atau kesalahan dari hipotesis nol. Ide kunci di belakang uji signifikansi adalah suatu uji statistik dan distribusi sampel dari suatu statistik hipotesis nol. Keputusan menerima atau menolak $\mathrm{H}_{0}$ dibuat pada basis nilai uji statistik yang diperoleh dari data yang sudah ada. Di bawah asumsi normalitas variabel mengikuti distribusi statistik $\mathrm{t}$ dengan derajat bebas $\mathrm{N}-\mathrm{k}$. 
Suatu statistik dikatakan signifikan secara statistik jika nilai uji statistik berada pada daerah kritis. Begitu pula sebaliknya apabila uji statistik dikatakan tidak signifikan. Dalam pengolahan uji statistik $t$ bertujuan untuk melihat seberapa besar pengaruh variabel independen terhadap variabel dependen secara individu. $t=\left[\beta_{s}-\beta\right] / \operatorname{se}\left(\beta_{s}\right)$.

Pengujian hipotesis nol dengan statistik $\mathrm{F}$ sangat perlu untuk menguji apakah $\beta_{\mathrm{k}}=0$. Perhitungan statistik $\mathrm{F}$ dari ANOVA dilakukan dengan membandingkan dengan nilai kritis $\mathrm{F}$ yang diperoleh dari tabel distribusi $\mathrm{F}$ pada tingkat signifikansi tertentu. Apabila hipotesis nol ditolak berarti variabel independen mempengaruhi variabel dependen. Dalam pengolahan empiris hal ini bertujuan untuk melihat pengaruh variabel independen secara bersama-sama terhadap variabel dependen.

Koefisien determinasi atau $\mathrm{R}^{2}$ merupakan ukuran goodness of fit yang menhelaskan apakah regresi linear sesuai dengan data observasi. Koefisien determinasi adalah suatu ukuran yang menjelaskan besar variasi regressan akibat perubahan variabel regressor. Koefisien determinasi mengukur proporsi atau persentase dari total variasi regressan yang dijelaskan oleh model regresi. Jika $R^{2}=1$ artinya hubungan regressan dengan regressor sempurna, sebaliknya $\mathrm{R}^{2}=0$ artinya tidak ada hubungan regressan dengan regressor. Dalam pengolahan empiris hal ini dilakukan untuk melihat seberapa besar model tersebut diterangkan oleh variabel yang ada.

\section{Pembahasan}

Dengan menggunakan regresi metode two stage least square terhadap persamaan identitas didapatkan konstanta sebesar: $\mathrm{Y}=-282.2403+2.699051$; Co+0.455426; I+0.859407; G. (-0,487486); (5,116559); (3,279000); (3,065884); $\mathrm{F}=18,88796 ; \mathrm{R}^{2}=0.877895$.

Hal ini berarti bahwa apabila semua variabel dianggap tidak ada, maka Y yang didapat adalah -282.2403 milyar rupiah. Sedangkan nilai koefisien Co, berarti bahwa peningkatan 1 persen nilai konsumsi, maka pendapatan daerah akan meningkat sebesar 2.69 persen. Nilai koefisien I, menandakan bahwa setiap kenaikan 1 persen nilai investasi maka pendapatan daerah akan meningkat sebesar 0.45 persen. Sementara nilai koefisien G, menandakan bahwa setiap kenaikan 1 persen nilai $\mathrm{G}$ maka pendapatan daerah akan meningkat sebesar 0.85 persen.

Pengolahan regresi menggunakan metode two stage least square pada persamaan identitas mendapatkan hasil uji t pada variabel Co (5.116559), variabel I (3.279000), dan variabel G (3.065884). Semua variabel uji t ini signifikan 
pada tingkat kepercayaan 5\%. Variabel Co mempunyai tanda '+' yang menunjukkan bahwa hubungan antara variabel Co dengan Y adalah positif. Hal ini berarti apabila Co meningkat, maka Y akan meningkat pula sebesar koefisien yang ada. Sementara variabel I mempunyai tanda '+' menunjukkan bahwa hubungan antara variabel I dengan Y adalah positif. Ini menandakan bahwa setiap peningkatan I akan diikuti dengan peningkatan Y. Dan G mempunyai tanda '+' yang menunjukkan bahwa hubungan antara variabel G dengan Y adalah positif. Hal ini berarti bahwa setiap peningkatan G maka $\mathrm{Y}$ akan meningkat pula. Sementara uji F yang didapatkan (18.88796) signifikan pada tingkat 5\%, hal ini karena nilai $\mathrm{F}$ hitung lebih besar daripada nilai $\mathrm{F}$ tabel. Tujuan dari pengujian $\mathrm{F}$ adalah untuk melihat seberapa besar pengaruh variabel independen yang ada terhadap variabel dependen secara bersama-sama. Sedangkan koefisien determinasi $\left(\mathrm{R}^{2}\right)$ yang didapatkan adalah sebesar 0.877895 . Hal ini dilakukan untuk melihat seberapa besar variabel independen mampu menjelaskan model.

Pengolahan pada persamaan konsumsi dimana terdapat zakat didalamnya didapatkan nilai koefisien: $\mathrm{Co}=367.3547 \quad(0,048880)+0.281943 \quad$ Yzm $(3,887257)+0.321621$ Yzs $(3,130343) ; \mathrm{F}=10,10525 ; \mathrm{R}^{2}=0,866959$. Nilai konstanta yang didapat memiliki makna bahwa apabila semua variabel independen sama dengan nol, maka tingkat konsumsi yang terjadi adalah 367.3547 milyar rupiah. Nilai koefisien Yzm berarti bahwa apabila terjadi kenaikan pendapatan muzakkî sebesar 1 persen maka konsumsi akan meningkat sebesar 0.28 persen. Variabel Yzs berarti bahwa apabila terjadi kenaikan 1 persen pendapatan mustahiq maka akan terjadi peningkatan konsumsi sebesar 0.32 persen.

Sedangkan pengolahan pada persamaan konsumsi mendapatkan nilai uji t pada variabel Yzm (3.887257) dan variabel Yzs (3.130343). Semua variabel uji t ini signifikan pada tingkat kepercayaan. Variabel Yzm mempunyai tanda '+', hal ini menunjukkan bahwa hubungan antara variabel Yzm dengan Co adalah positif. Ini menandakan bahwa apabila pendapatan muzakkî meningkat maka tingkat konsumsi akan meningkat pula. Sedangkan variabel Yzs mempunyai tanda '+' menunjukkan hubungan yang positif antara variabel Yzs dengan variabel Co, yang berarti bahwa setiap terjadi peningkatan pendapatan mustahiq maka tingkat konsumsi rumah tangga akan meningkat pula.

Nilai uji $\mathrm{F}$ yang didapatkan (10.10525) signifikan pada tingkat $5 \%$, hal ini karena nilai $\mathrm{F}$ hitung lebih besar daripada nilai $\mathrm{F}$ tabel. Ini dapat ditunjukkan dengan nilai prob yang ditampilkan. Hal ini untuk memperlihatkan apakah variabel independen yang ada secara bersama-sama berpengaruh terhadap variabel dependen Co. Koefisien determinasi $\left(R^{2}\right)$ yang didapat dalam per- 
samaan ini adalah 0.866959. Maksud perhitungan ini adalah untuk melihat seberapa besar model ini mampu dijelaskan oleh variabel independen yang ada.

Pada persamaan konsumsi konvensional dimana tidak terdapat zakat didalamnya didapatkan nilai koefisien sebesar: $\mathrm{Co}=1501.686+0.719152 \mathrm{Y}$. $(1,567554)(3,402312) . F=11,96479 ; R^{2}=0,850759$. Hal ini menunjukkan bahwa pada saat variabel $\mathrm{Y}$ sama dengan nol, maka tingkat konsumsi yang terjadi adalah 1501.686 milyar rupiah. Sementara nilai koefisien Y menunjukkan bahwa apabila terjadi peningkatan pendapatan sebesar 1 persen maka akan terjadi peningkatan konsumsi sebesar $0.71 \%$. Pengolahan pada persamaan konsumsi konvensional mendapatkan nilai uji t pada variabel Y (3.402312). Variabel $Y$ secara signifikan berpengaruh terhadap variabel Co. Variabel $\mathrm{Y}$ mempunyai tanda ' +', hal ini menunjukkan bahwa hubungan antara variabel Y dengan Co adalah positif. Ini menandakan bahwa apabila pendapatan meningkat maka tingkat konsumsi akan meningkat. Nilai uji F yang didapatkan (11.96479) signifikan pada tingkat 5\%, hal ini karena nilai $\mathrm{F}$ hitung lebih besar daripada nilai F tabel. Hal ini memperlihatkan bahwa seberapa besar pengaruh variabel independen yang ada berpengaruh secara bersama-sama terhadap variabel dependen. Ini dapat ditunjukkan dengan nilai prob yang ditampilkan. Koefisien determinasi $\left(\mathrm{R}^{2}\right)$ yang didapat dalam persamaan ini adalah 0.8507 . Nilai ini untuk menunjukkan seberapa besar variabel yang ada mampu menjelaskan model tersebut.

Berdasarkan pengolahan data yang telah dilakukan didapat angka-angka sebagai berikut: $\mathrm{Z}_{1}$ adalah $0.281943 ; \mathrm{Z}_{2}$ adalah 0.32161 . Angka-angka tersebut dapat dimasukkan dalam model persamaan di atas:

$$
\begin{aligned}
& Y=\frac{1}{(1-0.281943-0.32161)} \\
& Y=\frac{1}{0.396447} \\
& Y=2.522
\end{aligned}
$$

Hasil perhitungan yang didapat pada persamaan di atas, kemudian diperbandingkan dengan hasil perhitungan yang didapat pada persamaan ekonomi konvensional. Adapun persamaan ekonomi konvensional adalah sebagai berikut: $\mathrm{Y}=\mathrm{C}+\mathrm{I}+\mathrm{G}$. Di mana: $\mathrm{I}=\mathrm{Io}, \mathrm{G}=\mathrm{Go}, \mathrm{C}=\mathrm{a}+\mathrm{bY}$. Sehingga menjadi: $\mathrm{Y}=\mathrm{a}+\mathrm{bY}+\mathrm{Io}+\mathrm{Go}+\mu, \mathrm{Y}-\mathrm{bY}=\mathrm{a}+\mathrm{Io}+\mathrm{Go}+\mu$. Selanjutnya menjadi:

$$
Y=\frac{1}{(1-b)} a+I o+G o
$$


Sehingga multiplier pendapatan adalah:

$$
Y=\frac{1}{(1-b)}
$$

Apabila angka-angka yang didapat dari hasil pengolahan adalah: a adalah sebesar 1501.686; b adalah sebesar 0.719152 .

Sehingga apabila dimasukkan dalam persamaan menjadi:

$$
\begin{aligned}
Y & =\frac{1}{(1-0.719152)} \\
Y & =\frac{1}{0.280848} \\
Y & =3.561
\end{aligned}
$$

Berdasarkan perhitungan multiplier di atas terlihat bahwa multiplier yang dihasilkan oleh persamaan konsumsi konvensional tanpa memasukkan unsur zakat ternyata lebih besar apabila dibandingan dengan persamaan konsumsi dengan adanya unsur zakat didalamnya. Efek multiplier yang didapat memperlihatkan bahwa apabila dalam memasukkan unsur zakat dalam sistem perekonomian saat ini yang masih diliputi dengan sistem ekonomi kapitalis, maka zakat belum mampu memberikan pengaruh berarti dalam perekonomian.

Selain itu hal ini mempunyai implikasi bahwa pengelolaan dana zakat yang ada selama ini masih belum mampu meningkatkan tingkat konsumsi dari mustahiq, padahal seharusnya dengan teori yang ada zakat mampu memberikan efek multiplier yang besar terhadap tingkat pendapatan melalui mekanisme kenaikan daya beli mustahiq setelah menerima zakat dan selanjutnya berputar dalam suatu siklus ekonomi seperti terdapat dalam kerangka pemikiran teoritis pada penelitian ini

Dari hasil di atas terlihat pula bahwa kecenderungan mengkonsumsi pada suatu perekonomian dengan memasukkan unsur zakat di dalamnya lebih kecil bila dibandingkan dengan perekonomian tanpa adanya unsur zakat. Hal ini menjadi suatu hal yang wajar sebab Indonesia bukanlah negara yang menerapkan hukum syariat Islam dalam perekonomiannya serta tidak semua penduduk Indonesia pada umumnya dan Provinsi DKI Jakarta pada khususnya beragama Islam. Dengan kecenderungan mengkonsumsi yang kecil menunjukkan masih banyak yang belum menyadari betapa pentingnya bagi instrumen distribusi pendapatan di dalam suatu perekonomian. Mereka menganggap zakat masih seperti pajak yang hanya sebagai pengurang pendapatan semata. 
Hal ini sejalan dengan apa yang telah dilakukan oleh Fahim Khan dalam papernya yang berjudul The Macro Consumption Function in Islamic Framework, beliau melakukan perbandingan antara tabungan, pertumbuhan, dan pengaruh distribusi pendapatan dengan melakukan simulasi pada berbagai skenario berbeda. Berdasarkan simulasi yang dilakukan dapat disarankan bahwa apabila pemerintah hendak melakukan implementasi sistem zakat oleh legislasi. Secara singkat, untuk titik awal setiap pemerintahan melakukan penarikan zakat sebesar 2.5\% yang dilakukan dengan kebijakan untuk mengurangi konsumsi berlebihan (isrâf) baik untuk sektor publik maupun sektor swasta. Sehingga dalam simulasi yang dilakukan dapat disimpulkan bahwa dalam pemerintahan yang tidak Islami tidak dapat memaksimalkan peranan zakat dalam perekonomian.

Membandingkan dengan perhitungan yang dilakukan oleh Metwally (1993) aplikasi prinsip-prinsip Islam akan memberikan hasil yang berkelanjutan dan mungkin akan memberikan redistribusi pendapatan yang signifikan terhadap kaum miskin. Ini terkait dengan penegakan kewajiban atas zakat dan membangkitkan semangat untuk melakukan perbelanjaan di jalan Allah Swt. Efek distribusi yang dilakukan dalam prinsip Islam tergantung pada prilaku konsumsi masyarakat. Pada absolute income hypothesis, kita dalam mengharapkan bahwa redistribusi pendapatan dalam negara Islam sebagai hasil atas peningkatan konsumsi dan penurunan sumber daya yang tersedia bagi investasi. Melalui bukti empiris yang dilakukan terhadap 24 negara Muslim memberikan hasil bahwa efek distribusi dari prinsip Islam tidak akan memberikan hasil dalam meningkatkan jumlah konsumsi dan mengurangi jumlah tabungan yang digunakan untuk investasi. Hal ini terjadi karena dalam negara Muslim tidak menerapkan suatu perekonomian yang berbasis pada sistem ekonomi Islam seperti yang diasumsikan pada model yang ada.

\section{Penutup}

Besaran efek multiplier zakat-pendapatan yang dikelola oleh BAZIS DKI Jakarta adalah 2.522. Hal ini menandakan bahwa setiap penambaha sejumlah unit rupiah zakat yang dibayarkan, maka akan memberikan efek terhadap pendapatan sebesar 2.522 kali lipat. Apabila diperbandingkan dengan perekonomian tanpa memasukkan unsur zakat didapat angka 3.561, hal ini memberi implikasi bahwa lebih besar efek multiplier terhadap pendapatan dalam suatu perekonomian tanpa unsur zakat bila dibandingkan dengan perekonomian dengan adanya zakat. 
Kecilnya efek multiplier zakat bila dibandingkan dengan perekonomian tanpa ada unsur zakat terjadi karena ada beberapa hal. Pertama, masih jauhnya realitas penerimaan zakat apabila dibandingkan dengan potensi penerimaan yang bisa diterima. Kedua, alokasi penggunaan dana zakat yang diterima oleh mustahiq tersebut tidak dipergunakan sebagaimana mestinya. Sebagai salah satu contoh ada satu kasus di salah satu lembaga amil zakat, di mana mustahiq yang menerima bagian zakat fitrahnya yang berupa beras, ternyata dijual kembali dan dibelikan minuman keras. Ketiga, pengelolaan zakat yang masih harus lebih ditingkatkan profesionalitasnya baik dari segi SDM maupun infrastruktur penunjang lainnya. Keempat, Pemerintah masih kurang memberikan perhatian yang cukup bagi pengelolaan zakat, meskipun sudah terdapat UU yang mengatur tentang zakat namun itu masih belum optimal. Keempat, kurangnya koordinasi antar BAZ dan LAZ pengelola zakat, sehingga seringkali terjadi penumpukan penyaluran di satu tempat dan tidak tersentuhnya di tempat yang lain. []

\section{Pustaka Acuan}

Badan Pusat Statistik, Evaluasi Pelaksanaan Program Pengentasan Kemiskinan Terpadu 2000. Jakarta: BPS, 2001.

Blancahrd, Olivier, Macroeconomics, New York: Prentice Hall, 2003

Choudhury, Masudul Alam, Contribution to Islamic Economic Theory, London: Mac Millan, 1986.

Enders, Walter, Applied Econometric Time Series, New York: John Wiley \& Son Ins, 1995.

Gujarati, Damodar, Basic Econometrics, 3rd ed. Mc Graw Hill: New York, 1995.

Kahf, Monzer (ed), Economics of Zakah (a book of Readings), Jeddah, IRTI-IDB, 1997.

, The Principle of Sosioeconomic Justice in The Contemporary Fiqh of Zakah, Iqtishad Journal of Islamic Economic, Vol I, No. 1, Muharram 1420 H / 1999 M.

Khan, Fahim, The Macro Consumption Function in an Islamic Framework, Journal of Research in Islamic Economics, Jeddah: King Abdul Azis University, 1985.

Kuncoro, Mudrajad, Metode Kuantitatif: Teori dan Aplikasi Untuk Bisnis dan Ekonomi, Jogjakarta: UPP AMP YKPN, 2001.

Metwally, M. M., Essays on Islamic Economics, Calcutta: Academic Publisher, 1993.

Nata, Abudin, et. al., Pengelolaan Zakat dan Infak/Sedekah di DKI Jakarta, Jakarta: BAZIS DKI Jakarta, 1999. 
Qaradhawi, Yusuf, Hukum Zakat, alih bahasa Salman Harun, et. al., Jakarta: Pustaka Litera Antar Nusa dan Mizan, 1988.

Sadeq, Abu Al-Hasan, A Survey of The Institution of Zakah, Jeddah: IRTI-IDB, 1994.

Sekaran, Uma, Research Methods for Business, New York: John Wiley \& Son Ins, 2000.

Schmidt, Stephen J., Econometrics, New York: Mc Graw Hill, 2005.

Sugiyono, Statistik Penelitian, Bandung: Alfabeta, 1999. 